University of Colorado Law School

Colorado Law Scholarly Commons

Sustainable Use of the West's Water (Summer

Conference, June 12-14)

6-14-1995

\title{
The Oregon Watershed Health Program: Local Empowerment to Restore Watersheds
}

Mary Lou Soscia

Follow this and additional works at: https://scholar.law.colorado.edu/sustainable-use-of-west-water

Part of the Administrative Law Commons, Agriculture Commons, Dispute Resolution and Arbitration Commons, Environmental Law Commons, Environmental Policy Commons, Hydraulic Engineering Commons, Hydrology Commons, Natural Resources and Conservation Commons, Natural Resources Law Commons, Natural Resources Management and Policy Commons, Public Policy Commons, State and Local Government Law Commons, Sustainability Commons, Water Law Commons, and the Water Resource Management Commons

\section{Citation Information}

Soscia, Mary Lou, "The Oregon Watershed Health Program: Local Empowerment to Restore Watersheds" (1995). Sustainable Use of the West's Water (Summer Conference, June 12-14).

https://scholar.law.colorado.edu/sustainable-use-of-west-water/19

Reproduced with permission of the Getches-Wilkinson Center for Natural Resources, Energy, and the Environment (formerly the Natural Resources Law Center) at the University of Colorado Law School. 


\section{William A. Wise Law Library UNIVERSITY OF COLORADO BOULDER

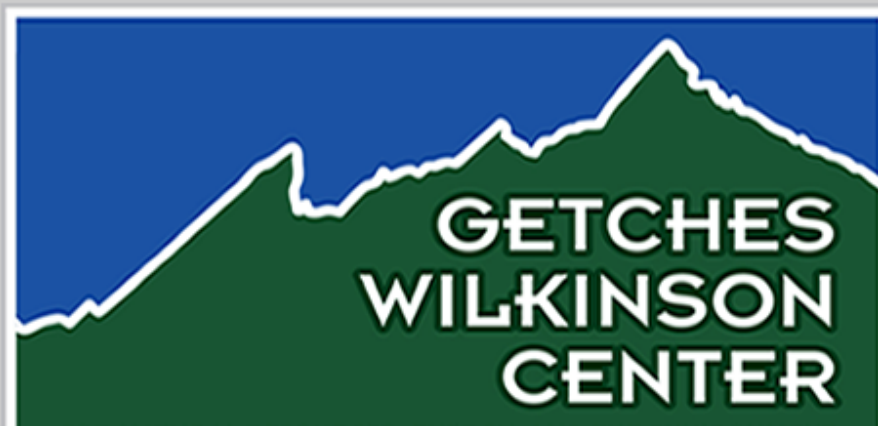 \\ FOR NATURAL RESOURCES, ENERGY, AND THE ENVIRONMENT \\ Getches-Wilkinson Center Collection}

Mary Lou Soscia, The Oregon Watershed Health Program: Local Empowerment to Restore Watersheds, in SUSTAINABLE USE OF THE WEST's WATER (Natural Res. Law Ctr., Univ. of Colo. Sch. of Law 1995).

Reproduced with permission of the Getches-Wilkinson Center for Natural Resources, Energy, and the Environment (formerly the Natural Resources Law Center) at the University of Colorado Law School. 


\title{
The Oregon Watershed Health Program: Local Empowerment to Restore Watersheds
}

\author{
Mary Lou Soscia \\ Program Manager \\ Oregon Watershed Health Program \\ Oregon Water Resources Department \\ 15812 th St. N.E. \\ Salem, OR 97310 \\ Sustainable Use of the West's Water \\ Natural Resources Law Center \\ University of Colorado School of Law \\ June 12 - 14, 1995
}


c 


\title{
The Oregon Watershed Health Program: Local Empowerment to Restore Watersheds
}

\author{
Mary Lou Soscia \\ May 1995
}

\section{INTRODUCTION}

In 1993, the state of Oregon created the Watershed Health Program as a part of new natural resource strategy acknowledging the critical importance of watersheds to Oregon's livability and economic health. This program was a commitment to encourage government and citizens to work together in developing voluntary plans for improving watershed health. This grew from a recognition that many Oregon watersheds no longer have the capacity to satisfy all demands placed on them by a growing population and economy. New listings of endangered species, widespread shortages for irrigation needs, growing disputes over water rights and degraded water quality were signs that a new cooperative approach to managing watershed was seriously needed.

To provide funding support, the 1993 Legislature allocated \$10 million in lottery funding to two areas, the Grande Ronde in Northeastern Oregon; and the South Coast and Rogue Basins in Southwestern Oregon (Senate Bill 81). The Grande Ronde Basin already had Snake River Chinook listed under the Endangered Species Act and the South Coast and Rogue Basins had potential listings looming around the corner with coastal coho and winter and summer steelhead. This pilot program, called the Oregon Watershed Health Program, was intended to bring better cooperation, between and among state agencies, and with local citizens in managing resources using a watershed framework and promoting voluntary actions to improve watersheds. The Strategic Water Management Group (SWMG), 13 state and 4 federal agencies and the Governor's office, were given oversight authority for watershed councils and the targeted basins. 
Since this pilot initiative got underway in January 1994, nearly 100 miles of stream banks have been planted with native vegetation to shade stream banks and hold runoff back. More than 300 in-stream enhancement structures have been placed in streams to slow currents and create fish habitat. More than 100 miles of fence have been erected to protect steam banks from grazing livestock. Seventeen fish screens have been installed on major Rogue basin water diversions to prevent fish from being stranded in ditches and fields. Even more significantly, however this pilot initiative has set up a process that deeply involves citizens in voluntary actions that improves water conditions and repairs the damages of historic activities.

\section{LOCAL WATERSHEd COUNCILS}

The cornerstone of this new initiative was the creation of local voluntary watershed councils to provide a forum for citizens to work in partnership with local, state, tribal and federal agencies to help solve watershed problems in their homes - the watershed in which they live. Legislation enacted in 1993 established state policy to support a watershed based approach by encouraging the formation of local watershed councils. Under the process described in the law (House Bill 2215) local watershed councils are appointed by local governments to work in partnership with natural resource agencies to develop and implement watershed action plans. House Bill 2215 did not include any funding but was specifically referred to in Senate Bill 81 which funded the Watershed Health Program. As a result of this policy direction, approximately 50 local watershed councils have been formed throughout Oregon, currently engaged in the management of their watersheds, and funding and completion of protection and restoration projects. Hundreds of people throughout Oregon are now participating with local watershed councils. 


\section{A Local/State Process}

The Watershed Health Program was based on the development of locally prepared watershed assessment and action plans which would be the blueprint for watershed restoration and protection efforts. With the program inception in January 1994, recognizing the need for time for local partnerships to form, the first activity was to fund early action projects. These early action projects included fish screening, tree planting, fencing and other restoration projects. Local watershed partnerships soon started forming and 13 local watershed councils were officially recognized by the state in the two areas. Multi-agency and multi-disciplinary field teams were established in each basin to provide an intensive technical boost to local efforts. Local watershed councils worked with these field teams, existing state agency field and central staff, interest groups, and other government agencies to characterize their watersheds, assess problems and work out ways to solve them.

Working in partnership with the diverse groups in each basin,, the watershed councils developed watershed action plans which identified watershed problems and needs and provided a blueprint for solutions. These plans characterized watershed conditions, identified priority areas of restoration and protection, set out public involvement strategies and identified funding sources to implement the plan. Action plans have been drafted for all basins in the Rogue and South Coast. The Grande Ronde Model Watershed Board of Directors has developed a basin wide operations plan and is in the process of developing action plans on a sub-basin level.

\section{Watershed Restoration AND Protection}

The Legislature earmarked $\$ 6.5$ million in lottery funds for projects in the two targeted basins and directed state agencies to get projects underway as soon as possible. Funding has been matched by a wide source of federal, state, local and private sources, at approximately $\$ .30$ to every $\$ 1.00$ in lottery funding. Over 150 projects have been 
completed or underway in the two areas. Here are a few examples of the projects begun with the aid of this funding:

- A total of 15,000 tree seedlings were planted along an eroded 10 mile stretch of the Illinois River where land practices - logging, draining, diking, and land clearing had created a degraded riparian area.

- In the upper Grande Ronde River in Union County, approximately 300 miles of roads are proposed to be closed on federal lands to reduce impacts to sensitive salmon habitat. - Logs and boulders were placed in stream along four miles of the South Fork of Little Butte Creek in Jackson County to improve fish habitat. Four off-channel alcoves were constructed to aid in the rearing of salmonids.

- More than 100 students participated in a study to improve habitat for salmon along a six mile stretch of Five Points Creek in the Upper Grande Ronde River.

\section{NEXT STEPS}

Governor John Kitzhaber has pledged to support Oregon's commitment to empowering local watershed groups through his 1995 - 1997 biennial budget. Two bills, one embodying the principles of working through watershed councils and the other identifying funding are currently moving through the Oregon Legislature. The first bill has a broad base of support and proposes to merge the highly successful Governor's Watershed Enhancement Board, a demonstration grant program, with the watershed council focus of the Watershed Health Program. The role of state agencies in decision making would occur by giving the Governor's Watershed Enhancement Board, a group of five natural resource commissioners, the decision making authority for grants to watershed councils for assessment, action plan development and implementation, monitoring, and education. The second bill, which will be more controversial, is the bill which identities the funding for the next biennium. It is expected that final decisions will be made by mid-June. 


\section{LESSONS LEARNED}

The Oregon Watershed Health Program was a bold new successful experiment which provides an important model for working on a watershed wide basis through local voluntary watershed councils. With the tremendous enthusiasm generated at the local level and the difficult natural resource controversies existing in communities around the country, it is widely recognized that this process is the future of natural resource management. As with any experiment, there are many lessons to be learned. These lessons may help states and communities develop successful local/state partnership for watershed management.

Lesson \#1 - Too much money too soon -- The Watershed Health Program had the onus of committing and spending close to $\$ 7$ million in projects in less than two years in two target areas. This caused vastly unrealistic expectations to provide money to watershed groups and having the money be well spent to get positive environmental results. This also caused a feeling of inequity in other watersheds in the state who had organized watershed councils and had projects ready to be funded.

Possible Solution: Funding should be committed with a rate of expenditure that follows a bell shaped curve. Initial funding should be to support watershed council start up and watershed assessment, action plan development, action plan implementation or projects, and monitoring and follow up evaluation of effectiveness. Government funding should be used as a catalyst to encourage local capacity building to support funding.

Lesson \#2: Funding tied to a political calendar. Many communities were hesitant to invest a lot of time in something that might be temporary whim of government. There was no commitment early on that this was a long term commitment in Oregon's watersheds. 
Possible Solution: Watershed health takes a long term commitment and requires an investment over time. Political commitments to watershed health must be long term and go beyond political time frames. Communication and public education must tie hand in hand with political time frames to convey in a local/state partnership a long term commitments to these issues.

Lesson \#3: Lack of integration of existing efforts into a pilot initiative. Oregon had a seven year successful watershed funding program, the Governor's Watershed Enhancement Board (GWEB), which funded individual demonstration and education projects through a citizens board. Many citizens were confused with the Watershed Health early action projects because they were difficult to distinguish from the GWEB projects.

Possible Solution: Ensure that policy discussions are held early on with affected government agencies, local interests and citizens' groups to integrate ongoing programs into a watershed approach to management. Another solution is to combine similar programs from the start to prevent confusion.

Lesson \#4: Too many layers for decision making. The SWMG decision making process was perceived as an unnecessary and burdensome decision making layer after watershed assessment, action plans and projects went through a long detailed process at the local level. Oftentimes, the decisions were made in a large public meeting with little opportunity for discussion.

Possible Solution: Watershed councils should be a bottoms up approach to decision making. The participation of government in local watershed councils assumes a partnership at the local level. A top down decision making structure is not appropriate for watershed councils. This is a delicate balance where to maintain accountability, established criteria for decision making is important. 
Lesson \#5: Not enough time to establish trust. Local watershed councils were expected to form and develop assessments, action plans plan and good projects in an unrealistic amount of time.

Possible Solution: When people start working together there is a trust factor which cannot be rushed. Government must recognize local groups need start up time to develop the trust necessary for people to work together.

Lesson \#6. Too much attention on projects. Funding was not specifically allocated for watershed assessment, monitoring or public education and involvement. Emphasis was placed on projects as a sign of success.

Possible Solution: Funding should be specifically allocated for essential elements of understanding watersheds, sharing information with the residents of the community and political leaders and monitoring the results of the work undertaken.

\section{Lesson \#7. State staffing were not experienced in working with a new a creative} process. A staff of 23 were hired with few with any experience in Oregon state government or watershed work. In addition, many were located in the field which causes great confusion at the local level with existing field staff.

Possible Solution: Provide funding at the local level to staff watershed councils, $\mathrm{d} d$ assessment work, develop and implement action plans, public involvement and monitoring. Use existing structures where possible to provide this support, for example, Soil and Water Conservation Districts. In addition, use local watershed council staff to work with local agency field personnel. 
